\title{
Pirmojo pasaulinio karo atminimas Lietuvoje ir Rytų Prūsijoje: naujų tyrimų pradžia
}

\author{
VASILIJUS SAFRONOVAS \\ Klaipèdos universiteto Baltijos regiono istorijos ir archeologijos institutas, Herkaus Manto g. 84, LT-92294 Klaipeda \\ El.paštas safronovas@gmail.com
}

\begin{abstract}
Straipsnyje vertinamos Pirmojo pasaulinio karo atminimo Lietuvoje ir Rytų Prūsijoje istorinių tyrimų galimybės. Karo istorijos vystymosi tendencijų kontekste aktualizuojama būtinybė tirti mentalinius ir socialinius Didžiojo karo poveikio Pietryčių Baltijos regiono visuomenèms aspektus. Siūlomos kryptys, kuriomis galètų būti plètojamos Didžiojo karo atminimo šiame regione studijos ir vertinama iki šiol atliktų tyrimų šia tematika situacija.
\end{abstract}

Raktažodžiai: Pirmasis pasaulinis karas, karo atminimas, atminimo istorija, lyginamoji prieiga, transnacionaliné prieiga

\section{IVADAS}

Šimto metų nuo Pirmojo pasaulinio karo sukaktis sujudino akademinę bendruomenę visoje Europoje (1). 2014 metų konferencijos, skirtos ịvairiems su šiuo karu susijusiems aspektams, skirtinguose senojo žemyno kampeliuose vyko kone kas antrą savaitę, o karui skirti pažintiniai ir akademiniai leidiniai pasipyle it iš gausybès rago. Ir šiemet neblèstantis dèmesys Didžiajam karui, tikètina, nenutrūks iki pat 2018-ųjų. Toks susidomëjimas šia „didžiąja embrionine šimtmečio katastrofa" (George F. Kennan), suprantama, skatina kelti klausimą, koks bus Lietuvos indèlis ị ši karo aktualizavimo etapą. O gal, dar kartą pasitenkinę redukcija, esą tai buvęs ne lietuvių karas, ir šịkart leisime, kad sukaktis Lietuvoje nesulauktų platesnio dèmesio?

Panašu, kad akademiniu lygmeniu karo poveikis Lietuvos visuomenei bent jau tam tikrais aspektais vis dèlto bus permąstytas. Kol kas taip teigti leidžia keli veiksniai. Pirmas tai - Vilniaus universiteto Istorijos fakultete šiemet baigtas vykdyti mokslinis projektas. Tomo Balkelio suburta tyrèjų grupé šiame projekte gilinosi i XX šimtmečio karų poveikị

(1) Straipsnis parengtas vykdant Lietuvos mokslo tarybos finansuojamą projektą „Pirmojo pasaulinio karo atminimas: Lietuvos ir Rytprūsių lyginamoji analizè (iki 1939 metų)" pagal mokslininkų grupių priemonę (sutarties Nr. MIP-021/2015). 
priverstinių iškeldinimų procesams Lietuvoje. Šio projekto pagrindinis rezultatas - dar nepublikuotas straipsnių rinkinys, kuriame keli tekstai bus skirti ir priverstinių iškeldinimų iš Lietuvos patirtimis, susijusioms su Pirmuoju pasauliniu karu. Antras - $2014 \mathrm{~m}$. gruodị Vilniuje surengta konferencija „Nacionalinis principas Pirmojo pasaulinio karo metais“. Konferencijos rengejjai - Lietuvos istorijos institutas kartu su Klaipėdos universiteto Baltijos regiono istorijos ir archeologijos institutu bei Šiaurès Rytų Europos vokiečių kultūros ir istorijos institutu (Lüneburg, Vokietija) - keliolika pranešèjų iš Lietuvos, Rusijos, Vokietijos, JAV, Lenkijos, Didžiosios Britanijos, Latvijos ir Čekijos sukvietė padiskutuoti apie nacionalinio ir imperinio principų sandūrą - sandūrą, kuri, be kita ko, sudarè sąlygas tarpti moderniam Lietuvos valstybingumui. Dalis straipsnių, parengtų šioje konferencijoje skaitytų pranešimų pagrindu, bus paskelbta $2015 \mathrm{~m}$. pabaigoje viename serijos Acta Historica Universitatis Klaipedensis tomų.

Trečiasis veiksnys, leidžiantis tikètis dèmesio Pirmajam pasauliniam karui lietuviškame diskurse, yra $2015 \mathrm{~m}$. Klaipėdos universiteto Baltijos regiono istorijos ir archeologijos institute pradètas vykdyti mokslinis projektas, skirtas šio karo atminimui Lietuvoje ir Rytų Prūsijoje iki 1939 m. palyginti (2). Diskutuojant su kolegomis apie sumanymą imtis tokio projekto, būta gana prieštaringų reakcijų. Vokiečiai, lenkai, rusai ir kitų šalių tyrèjai gyrè sumanymą ir dalijosi patarimais, kaip pasiekti geresnio rezultato, o Lietuvoje ne kartą kildavo klausimas, kaip galima tyrinèti tai, ko nebuvo. Iš dalies siekiant atsakyti ị tokio pobūdžio klausimus, šiuo tekstu norima pristatyti minèto projekto tyrimų trajektorijas, kartu įvertinant ligšiolinių tyrinéjimų situaciją. Tikimasi, kad čia pristatomi tiriamieji sumanymai paskatins Lietuvoje platesnę diskusiją klausimu, kaip tyrinèti karo atminimą šalyje, kuri pati tame kare nedalyvavo.

\section{KODĖL REIKIA ANALIZUOTI DIDŽIOJO KARO ATMINIMĄ LIETUVOJE IR RYTŲ PRŪSIJOJE?}

Atsakyti ị klausimą, kodèl Didžiojo karo atminimas Lietuvoje ir jos palyginimas su Rytų Prūsija nusipelnė atskiro dėmesio, galima išvardijant kelias pagrindines tokio tyrimo inicijavimo priežastis.

Pirmučiausia, akivaizdu, kad su Pirmuoju pasauliniu karu susijusios patirtys nei Lietuvoje, nei tose bendruomenėse, kurios patyrè tą karą Rytų Prūsijoje (turimi omeny vietiniai gyventojai, kurių dauguma neteko savo namų per ir po Antrojo pasaulinio karo), šiandieną nebèra reikšmingos. Antrojo pasaulinio karo ir iš dalies pokario patirtys nustūmè atminimą apie Didijj karą užmarštin. Ši bendra tendencija yra būdinga daugeliui Europos šalių. Europoje vyraujančiose atminimo kultūrose patys aktualiausi yra siužetai, susiję su Europos šalių totalitarine ir autoritarine praeitimi, ypač su Antrojo pasaulinio karo patirtimi, tik Vidurio Rytų Europoje tai apima ir pokario periodą, nuosekliai išvedamą iš šio siaubingo XX šimtmečio konflikto padarinių.

Lietuvoje Pirmojo pasaulinio karo viešą neaktualumą galima paaiškinti ir papildomais veiksniais. Vienas ju - Lietuva kaip valstybè pasauliniuose karuose nedalyvavo. Nacionalinès, kitaip tariant, valstybinès tradicijos minèti, atminti, aktualizuoti šị karą ir jo reikšmę Lietuvoje neatsirado. Tarp kitų priežasčių būtų galima ịvardyti ir tai, kad tarpukariu, tuo metu kai Didysis karas dideleje Europos dalyje buvo minimas, Lietuvos atminimo politikoje ir atminimo kultūrose daugiau dėmesio buvo skiriama nacionalinès valstybès sukūrimo faktui bei vèlesniems Nepriklausomybès karams. Iš esmès tai ne vien Lietuvos,

(2) Projekto tyrèjų grupę sudaro istorikai Vasilijus Safronovas (projekto vadovas), Vytautas Jokubauskas, Vygantas Vareikis ir Hektoras Vitkus. 
bet ir gerokai platesnio regiono bruožas. Čekoslovakijoje, Lenkijoje, Suomijoje ir netgi tokioje šalyje kaip Turkija Pirmasis pasaulinis karas dèl tos pačios priežasties tarpukariu netapo centriniu atminimo reiškiniu. Nors Lietuva nemėgsta būti lyginama su Rusija, šiuo požiūriu ji panaši ir ił pastarąją, tiksliau i TSRS, kurioje, kaip rodo prieš kelerius metus pasirodžiusi Karen Petrone studija [57], visus ịtraukiančio mito apie karą kūrimo pastangas - fragmentuotas ir neturèjusias aiškios vizijos - užgožė Spalio revoliucijos bei Pilietinio karo mitų konstravimas. Todèl atmintis apie daug Rusijos žmonių gyvybių nusinešusị ir galiausiai Romanovų monarchiją sužlugdžiusį konfliktą TSRS buvo daug labiau nei daugelyje Europos šalių "paskandinta" konkurencijoje su kitais atsiminimais [57, 7]. Trumpai tariant, Lietuva priklauso toms šalims, kurios susitelkẻ ị karo sukeltų revoliucinių permainų ir jų iškovojimų atminimą, dažnai, beje, nesiejant jų su Didžiuoju karu.

Rytų Prūsijoje, atvirkščiai, Didysis karas tarpukariu, be jokios abejonès, buvo aktualus. Su juo susijusios reikšmės aktyviai eksploatuotos ir dèl politinių tikslų. Tačiau Antrasis pasaulinis karas, konkrečiau - pasitraukimo iš savosios žemés patirtis paskutiniais karo etapais, vèliau redukuota ị vadinamąji bejgimo ir išginimo (Flucht und Vertreibung) topą, užgožè Pirmojo karo svarbą ir rytprūsiečiams.

Inicijuojant Didžiojo karo atminimo tyrimą, nėra siekiama giliai analizuoti priežasčių, kodèl šis karas nūdienos atminimo tradicijose nebẻra aktualija Lietuvoje. Juolab kad ši klausimą savo straipsnyje jau gvildeno Algimantas Kasparavičius, išryškinęs daugelio Didžiojo karo ženklų ir simbolių Lietuvoje sąmoningo griovimo tendenciją tarybinio laikotarpio pradžioje [36, 58-60]. Lygiai nesiekiama aiškinti, kodèl, antra vertus, Kaliningrado srityje praeitais metais karas buvo aktualizuotas, taip pat ir statant naujus paminklus. Veikiau bus siekiama rekonstruoti, kaip Didysis karas buvo sureikšmintas ir koks buvo atminties apie ši karą klodas, kol dar jis nebuvo sujauktas ir transformuotas Antrojo pasaulinio karo patirties. Būtent todèl tyrimas sąmoningai apribojamas laikotarpiu iki 1939 metų.

Antrąją priežastị būtų galima ịvardyti kaip norą Lietuvoje karo istoriją plètoti tokiu interpretaciniu lygmeniu, koks yra pasiektas kituose, pirmiausia, žinoma, „Vakarų“ Europos kraštuose. Ne paslaptis, kad karo istorija iki labai neseno laiko Lietuvoje buvo rašoma kaip mūšių ir karvedžių, geriausiu atveju - dalinių ir junginių, istorija, kurioje buvo daug skaičių ir faktų, tačiau kuri nepažengė toliau aprašomojo lygmens. Taigi karo istorija buvo plètojama tarytum koks autonominis tyrèjų, besidominčių ginklais, karinemis operacijomis ir kareiviais, domenas. Geriausiu atveju ji igydavo monumentalias naratyvines formas, kurių kanonas mažai pakito nuo Herodoto ir Tukidido, aprašinejjusių antikos karinius konfliktus, laikų. Tačiau tokiuose naratyvuose ilgą laiką nebuvo bandoma atliepti bendrų istoriografijos plètojimosi iššūkių, kuriuos XX šimtmetyje jiems iškèlè visų pirma socialiniai mokslai, o paskui ir vadinamasis „lingvistinis posūkis“.

Tad ir daug kas iš to, kas buvo rašoma apie Pirmajji pasaulinị karą Lietuvos istorikų, iki labai neseno laiko irgi buvo tokio lygmens aprašymai, kuriuos, beje, galima suskaičiuoti ant pirštų. Išskyrus vieną kitą bandymą pasekti lietuvių karių likimus Rusijos daliniuose [58], iki šiol neturime netgi detalaus lietuvių karių arba karių iš Lietuvos, tarnavusių Rusijos ir Vokietijos kariuomenèse, tyrimo. Lietuvos istoriografijoje, kalbant apie Pirmojo pasaulinio karo pažinimą, yra labiau ištyrinètas tik Vokietijos okupacinės politikos rytuose užimtose teritorijose, vadinamojoje Ober Osto žemèje, klausimas [28; 13; 10; 46; 51]. Prie tokių tyrimų yra reikšmingai prisidejjęs ir Lietuvoje pokariu dirbęs istorikas Aba Stražas, pirmuosius straipsnius šia tema paskelbęs 1958 m. TSRS Mokslų akademijos žurnale Bonpocы историu, o apibendrinęs savuosius tyrimus $1993 \mathrm{~m}$. Vokietijoje išleistoje monografijoje [70]. 
Tam tikru bandymu toliau plètoti šią tematiką galima laikyti $2011 \mathrm{~m}$. Vokietijos istoriko Christiano Westerhoffo išleistą monografiją [80], skirtą Vokietijos okupacinès valdžios darbo jègos mobilizavimo politikai Lenkijoje ir Lietuvoje.

Vis dèlto žvilgtelèję šiuo klausimu ị didžiąsias Vakarų Europos šalis, išvysime, kad ten Pirmojo pasaulinio karo istoriniai tyrimai, skirtingai nei Lietuvoje, jau senokai peržengè karo veiksmų aprašymo lygmenị. Iš tiesų tą lygmenị jau po Antrojo pasaulinio karo pakeitė studijos, kurias Belinda Davis yra apibūdinusi kaip „istorijas apie pagrindines strategijas ir strategus" $[16,113]$. Dabar, galima sakyti, yra pereita ị kitą Didžiojo karo interpretacijos fazę, kurioje istorikus, neišskiriant karo istorikų, domina skirtingos socialinès ir mentalinès karo metų patirtys: kasdienybès atkūrimas remiantis išlikusiais karo lauko pašto laiškais (pradedant Berndo Ulricho ir Benjamino Ziemanno tyrimais [21]), karinis turizmas, dženderiniai aspektai ir moters vaidmuo kare, vyrų maskuliniškumas ir seksualumas kare [15], erdvės suvokimas kare [57], galiausiai karo propaganda ir karo recepcija. Tai ypač pasakytina apie Vokietijai skirtą istoriografiją, bet taikytina ir kitoms šalims, pvz., Prancūzijai ar Britanijai. Šių tyrimų kontekste taip pat būtų galima išvardyti ne vieną studiją, nagrinejjančią îvairius Pirmojo pasaulinio karo atminimo aspektus skirtingose Europos dalyse, bet apie tai kiek vèliau.

Lietuvos atveju klausimai, kokią ịtaką Didysis karas padarè mentaliniams, socialiniams pokyčiams, kol kas keliami labai vangiai, tačiau tam tikra pažanga šia linkme jau yra padaryta. Lietuvos medžiaga yra stipriai paremta standartiniu veikalu apie Didžiojo karo Rytų frontą pasaulineje istoriografijoje tapusi JAV istoriko Gabrielio Vèjo Liulevičiaus studija [49] apie Vokietijos karių patirtis Rytų fronte ir jų ịtaką „vokiškam“ požiūriui ị Rytų Europą. Šioje studijoje, tiesa, nekeliamas klausimas apie karo patirčių poveikị visuomenès mentalitetui ir identitetui Lietuvoje. Iš pastarojo tipo tyrimų būtų galima išskirti viso labo kelis T. Balkelio straipsnius apie Didžiojo karo karių demobilizaciją ir karo pabėgèlių grị̌imą i Lietuvą $[4 ; 7 ; 3 ; 2]$ bei pernai publikuotą Andrea Griffante’s tyrimą, nukreiptą ì Ober Osto žemèje likusių lietuvių karo patirtis, kurias autorius daugiausia pabandè rekonstruoti iš atsiminimų ir dienoraščių [27]. A. Griffante taip pat yra publikavęs tekstą, skirtą konkretiems vokiečių ịvaizdžiams, formuotiems Lietuvoje per karą [26]. Be šių tyrimų, dar būtų galima išvardyti kelis straipsnius, kuriuose buvo paliestas karo atminimas Lietuvoje (apie juos truputị vèliau). Tačiau tai ir viskas.

Inicijuojant tyrimą apie karo atminimą Lietuvoje ir Rytų Prūsijoje, Lietuvos istoriografijoje siekiama analizuoti būtent socialinius ir mentalinius Didžiojo karo sąlygotus pokyčius. Taip, viena vertus, norima plètoti kokybiškai naujus šio konflikto ir apskritai karo istorijos tyrimus Lietuvoje, antra vertus, siekiama formuoti naujas susikalbejjimo su tarptautine tyrèjų bendruomene galimybes, sudominant tą bendruomenę lietuviška medžiaga.

Čia priarteju prie trečiosios priežasties, kodèl pradedamas tyrimas apie karo atminimą. Ją būtų galima ịvardyti kaip norą paskatinti tyrèjų bendruomenę atkreipti dèmesi $\mathfrak{i}$ Pietryčių Baltijos regioną, tokị tyrimą internacionalizuojant.

Jungiančiosios temos, kurios buvo pasirinktos tarptautinėms Pirmojo pasaulinio karo asociacijos (International Society for First World War Studies) konferencijoms, ligi šiol vykusioms Londone, Insbruke ir Paryžiuje, rodo, kad pastaraisiais metais vis akivaizdžiau suvokiama - su Vakarų frontu Europoje susiję ịvaizdžiai vis dar nustato pasakojimo apie Pirmąji pasaulinį karą kanoną, ir šią padètị reikia keisti. Tokią padètị iš esmès charakterizuoja ir tokie straipsnių rinkinių pavadinimai, kaip antai „Užmirštasis frontas. Rytai 1914-1915-aisiais“ [76]. Akademiniu lygmeniu apie Didiji karą pasaulyje, deja, taip pat vis 
dar dažniausiai pasakojama iš Vakarų ir geriausiu atveju - Vidurio Europos perspektyvos. Pietų ir Rytų Europa tipiniuose karo aprašymuose figūruoja gerokai rečiau, o Pietryčių Baltijos regionas ị tuos aprašymus paprastai patenka gal tik dèl 1914-ųjų Tanenbergo mūšio sureikšminimo tradicijos.

Projekto tiriamojo objekto geografinè imtis - Pietryčių Baltijos regionas - leidžia tikètis, kad medžiaga, kurią ketinama pateikti, neatrodys neaktuali ir tarptautiniame kontekste. Atvirkščiai, informacijos apie šį regioną bent jau anglų ir amerikiečių istoriografijoje iki šiol labai trūksta.

\section{TIRIAMOJI PRIEIGA IR TYRIMO PJŪVIAI}

Kuo ketinama sudominti Lietuvos ir tarptautinę auditoriją tiriant Pirmojo pasaulinio karo atminimą Lietuvoje ir Rytų Prūsijoje? Čia išskirčiau du konkrečius aspektus, t. y. prieigą, kurią ketinama taikyti, ir konkretų tiriamaji pjūvị.

Pirmojo pasaulinio karo atminimas Europoje istorikų dažniausiai analizuojamas apsiribojant nacionaline atminimo erdve. Paminklai, skirti žuvusiesiems kare [pvz., 8; 37], atsiminimų apie karą konkurencija tarpukariu [pvz., 40; 79; 84], karo medijavimas ir reprezentavimas [39], susidorojimas su „karo neuroze“ ir jos politinis įveiklinimas [14], - visa tai tiriama vienos nacijos kontekste. Iš tokios tematikos studijų tyrimas, atliekamas igyvendinant aptariamą projektą, pirmiausia skiriasi lyginamosios prieigos pasirinkimu. Tokios prieigos taikymas šiam klausimui analizuoti, suprantama, nèra naujas. Yale'io universiteto istorikas Jay'us Winteris savo klasikinėse studijose Pirmojo pasaulinio karo atminimą yra parodęs kaip bendraeuropinị reiškinị. Studijoje "Atminties vietos, gedulo vietos“ [82] bei vèliau išleistoje knygoje „Prisimenant karą“ [81] jis aptare su karu susijusių atminimo ir gedulo praktikų susiformavimą, karo mitologizavimą filmuose, mene, karo literatūroje ir poezijoje (ankstesnị bandymą atlikti kažką panašaus pasiremiant vien Britanijos pavyzdžiu žr. [22]). Abiejose studijose ị karo atminimą bandyta pažvelgti neapsiribojant viena kažkuria valstybe, visgi abi knygos daugiausia buvo paremtos Britanijos, Prancūzijos, Vokietijos pavyzdžiais. Prie lyginamųjų studijų galima priskirti ir Stefano Goebelio tyrimą [25]. Šis autorius reikšmėse ir praktikose, kurios buvo aktualizuojamos atmenant karą, ieškojo viduramžių tęstinumo, to, ką jis pats ịvardijo „medievilizmu“, apraiškų. Tačiau šiame tyrime jis vèlgi lygino Britanijos ir Vokietijos, kitaip tariant, eilinį kartą Vakarų Europos atvejus. Išskyrus kelias išimtis, orientavimasis ị „Vakarų pasaulio“ pavyzdžius vyrauja ir pačiuose naujausiuose veikaluose, skirtuose karo atminimui, pvz., tik šiemet pasirodžiusiame Barto Ziino redaguotame straipsnių rinkinyje [60].

Projekto metu atliekamas tyrimas nuo tokių lyginamųjų karo atminimo studijų skiriasi susitelkimu ị vieną regioną, sudariusį tą patị karo veiksmų teatrą. Bus tiriamas patirčių, susijusių su Europos Rytų frontu, aktualizavimas, o Rytų fronto patirtys lyginamosios perspektyvos taikymo iki šiol sulaukdavo retai.

Panašų tyrimą apie vieno karo veiksmų teatro virsmą atminties ištekliumi Vokietijoje yra atlikusi Susanne Brandt, tačiau jos studija taip pat buvo skirta buvusiai Vokietijos vakarinio fronto teritorijai [9]. Diuseldorfo universitete apgintoje disertacijoje ji aiškinosi, kaip Vokietijoje dar per karą èmè formuotis naratyvinès Vakarų fronto aprašymo struktūros ir kaip tarpukariu, konkrečiai iki 1940 m., kai, anot autorès, buvo išspręstas „karo pralaimejjimo gedos" klausimas, Vakarų frontas ir atskiros jo vietos buvo sureikšminamos viešojoje bendravimo erdvejje. S. Brandt tyrimas laikytinas pavyzdžiu, kaip nagrinėti karo reikšmių sąsają su specifiniu landšaftu, tačiau jis, kaip sakyta, vèlgi apsiribojo reikšmėmis vienoje nacionalinejje kultūroje. 
Kita vertus, su karu susijusių ịvaizdžių formavimasis priešingose fronto pozicijose irgi nèra nenagrinėta tema. Istorikas Aribertas Reimannas 2000 m. išleido studiją, kurioje trylikoje dienraščiu ir daugiau kaip 7 tūkst. lauko pašto laiškų analizavo, kaip Vokietijos ir Britanijos propagandoje ir bendresne prasme karo metų retorikoje funkcionavo istoriniai ịvaizdžiai [59]. Iš esmès tai yra diskurso analizè, kuri vèlgi sutelkiama ị Vakarų Europos patirtis, nors ir apima dvi skirtingas valstybes.

Aptariamame projekte nauja tai, kad dauguma šių klausimų bus paliesta lyginant karo sureikšminimą ir atminimą ne dviejose valstybėse, kurios buvo aktyvios karo dalyvès, bet dviejose visuomenėse, vienodai patyrusiose karą, tik skirtingai ji sureikšminusiose. 1923 m. atlikto gyventojų surašymo metu pavyko surinkti duomenis apie 64628 Didžiojo karo dalyvius iš Lietuvos (be Klaipeddos krašto), iš kurių 11173 asmenys buvo laikomi žuvusiais kare [45, 307]. Iš buvusio Lietuvos vidaus reikalų ministro Rapolo Skipičio, kuris Rusijoje rūpinosi lietuvių pabėgèlių reikalais, o vèliau koordinavo organizuotą tremtinių ir pabėgèlių grąžinimą i Lietuvą iš Rusijos, atsiminimų žinoma, kad apytiksliai 550 tūkst. Lietuvos gyventojų (iš jų 250 tūkst. lietuvių, 160 tūkst. žydų, ne mažiau 90 tūkst. rusų, apie 50 tūkst. lenkų ir kt.) 1915 m. pasitraukè arba buvo priverstinai iškeldinti ị Rusijos gilumą [67, 258]. Tačiau lietuviškas variantas to, ką George’as Lachmannas Mosse’as kadaise įvardijo „karo patirties mitu“ (the Myth of War Experience) [54, 7], atrodo, nebuvo sukurtas. Pagal dydi $i$ Lietuvą panašioje Rytų Prūsijoje Rusijos kariuomenès ịsiveržimų metu žuvo apie 28 tūkst. Vokietijos karių [17, 11], 1,5 tūkst. civilių, apie 13,5 tūkst. rytprūsiečių 1914-1915 m. buvo ištremta į Rusijos gilumą [24, 229, 246], o iš viso per ketverius metus ị kariuomenę mobilizuota 600 tūkst. Rytų Prūsijos vyrų [43, 204]. Taigi Rytų Prūsijos atveju susiduriame su didesniu nuošimčiu asmenų, kuriuos tiesiogiai palietė karas, bet tikrai ne vien tai paaiškina, kodèl Rytų Prūsijoje nuo pat karo pradžios buvo pradètas formuoti „karo patirties mitas“.

Tad tyrimu objektyvuojamas arealas išsiskiria: 1) Rytų fronto specifika - o Rytų frontas, skirtingai nei Vakarų, nebuvo „stabilus“; jo slinkimosi apimtys ties Rytprūsiais ir Lietuva siekè 300-400 km; 2) įvairiu mastu tą arealą palietusiomis vienodomis karo patirtimis, bet skirtingu karo sureikšminimu: Rytų Prūsijoje karo patirtys buvo nacionalizuotos, paverstos nacionalinès kultūros dalimi, o Lietuvoje - ne. Visa tai, manyčiau, atveria plačias perspektyvas taikyti lyginamąj metodą. Vis dèlto šio metodo taikymas pats savaime dar nepadeda išsilaisvinti iš nacionalinès perspektyvos. Taikant vien ši metodą, bet kokiu atveju įmanoma parodyti reiškinị iš skirtingų ar panašių - priklausomai nuo to, kas lyginama, - nacionalinių perspektyvų - vokiškos ir lietuviškos.

Būtent todèl ị aptariamą tyrimą siekiama įtraukti transnacionalinę prieigą. Rašyti istoriją iš transnacionalinès perspektyvos, reiškia nagrinėti reiškinį, kurio raiška neapsiriboja nacionalinèmis sienomis. Ši prieiga paprastai taikoma tiriant žmonių, idejjų, technologijų ir institucijų judejjimą per nacionalines sienas. Kitaip tariant, ji pirmiausia taikoma tiriant judejjimus ir galias, kurios yra kirtusios nacionalines ribas [33, 213]. Visgi platesne prasme transnacionalinè istorija skiria dèmesị patiems tinklams, procesams, įsitikinimams ir institucijoms, peržengusioms valstybių, imperijų ir pan. darinių ribas $[1,1459]$. Būtent taip suvokiant šią prieigą, yra prasminga analizuoti ne tik karo veteranų tinklus, apėmusius kelias valstybes, bet ir su karo atminimu susijusių procesų ir ịsitikinimų istoriją. Trumpai tariant, yra prasminga tirti Pirmojo pasaulinio karo atminimą ne vien iš nacionalinès perspektyvos, bet pažvelgti $\mathfrak{i}$ tą atminimą kaip ị bendresnị transnacionalinị fenomeną, vietoj klausimo, kaip karas buvo atmenamas atskirai Lietuvoje ar Rytų Prūsijoje, klausiant, kokias konfigūracijas ir transformacijas tas pats reiškinys - skirtingų karo patirčių sureikšminimas ir atminimas - igauna esant 
skirtingoms socialinėms ir politinėms sąlygoms, kuriomis kaip tik ir pasižymėjo du skirtingi regionai: Lietuva ir Rytų Prūsija.

Ypač i̇domūs reiškiniai šiuo atveju turètų atsiskleisti Klaipėdos krašto teritorijoje, kuri tarpukariu priklause Lietuvai, bet kurioje kirtosi kelios Pirmojo pasaulinio karo atminimo ir vertinimo tradicijos - mažų mažiausiai vokiška rytprūsietiška ir lietuviška. Tiriant, kaip karo atminimas reiškèsi Klaipėdos krašte, yra prasminga taikyti ir histoire croisée (Michael Werner ir Bénédicte Zimmermann) bei „kultūrinių transferų“ (Michel Espagne ir Michael Werner) prieigas, kurios pasižymi siekiais analizuoti įvairių praeities fenomenų raišką tose terpėse, kuriose kertasi skirtingos kultūrinès ir socialinès tradicijos.

Transnacionalinę prieigą taikyti, taigi nacionalinius suvokimo rẻmus peržengti, tiriant Didžiojo karo atminimo klausimą, skatina vien faktas, kad Lietuvoje tarpukariu nebuvo politiškai sankcionuotos šio karo atminimo tradicijos, bet tai dar nereiškia, kad karas išvis nebuvo aktualus visuomenei, kuri vienaip ar kitaip ji išgyveno. Siekiant užčiuopti ši aktualumą, buvo pasirinkti specifiniai tiriamieji pjūviai, ir jų pasirinkimas yra antrasis šio projekto naujumo aspektas.

Objektą, kuris bus tiriamas aptariamame projekte, ir būdus, kuriais jis bus tiriamas, smarkiai veikia tiek teorinė prieiga, tiek ir autorių, konkrečiai nagrinejjusių karo atminimą, studijos. Teorinè prieiga šiame projekte daugiausia paremta klasikinių atminties kaip socialinio ir komunikacinio reiškinio analitikų Maurice’o Halbwachso, Pierre’o Nora, Jano ir Aleidos Assmannų, Astrid Erll darbais. Tyrime remiamasi jų konceptualizuotomis „kolektyvinès atminties“, „,atminimo kultūrų“, „, atminties vietų“ sampratomis, kurias ketinama taikyti atsižvelgiant i patirtị, igytą Lietuvoje realizuojant kelis mokslinius projektus, skirtus atminimo kultūrų kaitai XX a. Lietuvos miestuose [63; 62].

„Kolektyvinès atminties“ samprata šiame projekte verčia žiūrèti ị karo patirtị kaip ị tam tikrą bendruomeniškumą kuriančius atminties socialinius rèmus. Skirtingos karo patirtys skirtingais būdais susiejo arba, atvirkščiai, potencialiai supriešino įvairias visuomenès grupes, ir pirmasis tyrimo uždavinys yra pabandyti šiuos karo patirčių nulemtus socialinius saitus rekonstruoti. Sykiu projekto tyrëjų grupei rūpès ne vien tai, kaip šie saitai susiformavo karo metais, bet labiausiai tai, kokių komunikacinių sąlygų tiems socialiniams saitams toliau palaikyti būta arba nebūta po karo.

"Atminimo kultūrų" samprata kreipia ị informacinị arba reikšminị analizès lygmenị. Čia pagrindinis klausimas projekto tyrejjams - ką iš visų tų šaltinių, kurie leidžia identifikuoti atminimo kultūrų turini, galima pasakyti apie tam tikrus atminties modusus: ar atminimo kultūrose buvo įtvirtinamas aukos, budelio, nugalètojo ar pralaimètojo statusas, kaip spręstas atsakomybės klausimas? Tiriant atminimo kultūras, yra svarbu ne vien analizuoti diskursą, bet ir susieti viešai produkuojamą diskursą su konkrečiomis grupėmis, kurios ji produkuoja. Būtent todèl būtina turèti omenyje atminimo kultūros ir kolektyvinès atminties santykị, suvokiant jị kaip santykị tarp reikšmių sistemos ir žmogaus arba santykị tarp reikšmių sistemos ir to, kokias prasmès variacijas ji igauna tam tikrame kolektyve. Tas santykis nèra vienpusis: ne tik atminimo kultūros formuoja kolektyvines atmintis, bet ir patys žmonès formuoja atminimo kultūrų turinị, aktualizuodami vienas reikšmes, kurias suteikia praeities simboliams ir vaizdiniams, ir, antra vertus, deaktualizuodami kitas.

Galiausiai „atminties vietų“ samprata ragina susikoncentruoti ị simbolius, vietas ir landšaftus, kurie buvo asocijuojami su karu. Konkrečios atminties vietos reikšminio turinio, jos simbolinès ir socialinès funkcijos nesuprasime, nesusiedami jos su konkrečia atminimo kultūra, kuri tą vietą sureikšmina, ir čia vėlgi matome sąsajas tarp „atminimo kultūrų“ 
ir „atminties vietų“ konceptų. Kartu atminties vietas reikia skaityti tam tikro istorinio arba mitinio pasakojimo kontekste, nes būtent toks pasakojimas yra atminimo kultūros reikšmių sąryšius reguliuojantis naratyvas.

Kalbant apie toki pasakojimą, vèl tenka grịžti prie G. L. Mosse’o „karo patirties mito“ sąvokos, suvokiant tokio mito paieškas kaip dar vieną uždavinị, kurio igyvendinimas leidžia perskaityti konkrečiuose simboliuose koduojamas reikšmes. Standartiniu istoriografijos veikalu tapusi G. L. Mosse’o studija apie politinị karo eksploatavimą šiame tyrime skatina kelti dar vieną klausimą - kaip karo patirtys yra ịvaldomos politiniuose mūšiuose. Atkreipti ị tai dèmesị neišvengiamai verčia ir kitų istorikų darbai. Iš jų pirmiausia išskirčiau Reinharto Kosellecko tekstus [42; 41], skirtus karių paminklų simbolinei analizei bei žuvusių karių politiniam įvaldymui, bei B. Ziemanno darbus, skirtus karo veteranų organizacijų politinio vaidmens tarpukario Vokietijoje paieškoms bei skirtingų karo veteranų draugijų atsiminimų politinei konfrontacijai.

Visa tai leidžia teigti, kad Pirmojo pasaulinio karo sureikšminimą ir atminimą Lietuvoje ir Rytų Prūsijoje yra būtina analizuoti trimis lygmenimis, kuriuos sąlygiškai vadinu diskursyviniu, socialiniu ir praktiniu.

1. Diskursyviniu lygmeniu keliamas klausimas, kokia karo patirtis buvo sureikšminta ir kokiais būdais tai buvo daroma. Konkrečiai čia tikimasi atskleisti okupacinès administracijos, „Vokiečio“, „ruso“ ir kt. ịvaizdžių formavimąsi ir funkcionavimą karo metais, okupacijų mitologizavimą ir stereotipizavimą atitinkamai Lietuvoje ir Rytų Prūsijoje, nustatyti diskurso apie Vokietiją ir vokiečius / Rusiją ir rusus tęstinumą po 1918 m., karo dèmens vaidmenį diskurse apie ūkio ir miestų atstatymą Lietuvoje ir Rytprūsiuose, karo metų tremties ir priverstinių iškeldinimų vaidmenį diskurse, trumpai tariant, palyginti karo patirties reprezentavimą abiejuose kraštuose.

2. Socialiniu (atminimo nešèjų) lygmeniu keliamas klausimas, kokių būta karą patyrusių socialinių grupių ir koks buvo jų vaidmuo sureikšminant ir ịprasminant karą. Konkrečiai čia tikimasi palyginti veteranų, nukentejjusiųjų kare, ir kitų formalių ar neformalių asociacijų vaidmenį Lietuvoje ir Rytprūsiuose 1918-1939 m., nustatyti šių socialinių grupių organizuotumą, ryšius su tarpukariu veikusiomis sukarintomis ir politinèmis organizacijomis, poveiki įtraukiant karo tematiką ì muziejų veiklą, ugdymo procesą ir ittaką kuriant karui atminti skirtus ritualus.

3. Praktiniu lygmeniu keliamas klausimas apie karo sureikšminimo ir atminimo praktikas, pasireiškusias Lietuvoje ir Rytprūsiuose. Čia siekiama išanalizuoti mūšių ir karo aukų i̇amžinimą, karo muzealizavimą, vaidmenị edukacijoje, atminimo ritualizavimą bei nustatyti karo atminimo pasitelkimo politiniams interesams mastą.

Šių trijų lygmenų tyrimas, tikimasi, leis pateikti originalų Pirmojo pasaulinio karo atminimo Pietryčių Baltijos regione vertinimą.

\section{LIGŠIOLINIŲ TYRIMŲ PADĖTIS}

Iš kitų panašaus pobūdžio karo atminimo studijų, kurios jau buvo trumpai pristatytos, Klaipeddos universiteto Baltijos regiono istorijos ir archeologijos institute pradedamas tyrimas išsiskirs ne vien lyginamąja ir transnacionaline prieiga bei specifiniais tyrimo pjūviais, kuriuos verčia pasirinkti karo atminimo tyrimas dviejose visuomenèse. Nemažiau svarbu pabrèžti, kad atliekant ši tyrimą, tikimasi tam tikro proveržio Pirmajam pasauliniam karui skirtoje istoriografijoje, kurioje daugelis suminètų aspektų iki šiol tèra ištirta sporadiškai. 
Solidų indèlị ị antivokiškos karo metų propagandos Rusijoje bei antirusiškos karo metų propagandos Vokietijoje ir jos įtakos Rusijos ịvaizdžio susiformavimui tyrimus įnešè bendro Rusijos ir Vokietijos tyrëjų projekto, skirto abipusiams Rytų ir Vakarų i̇vaizdžiams, vadinamojo Vupertalio-Bochumo projekto vykdytojai. Šie klausimai aptariami Peterio Jahno, Thomaso Schneiderio, Lasisos Korovinos ir Tatjanos Filipovos straipsniuose, kurie pagal minètą projektą $2005 \mathrm{~m}$. buvo paskelbti Vokietijoje [34; 38; 19; 66; dar žr. parodos katalogą: 75], o vèliau, išversti ị rusų kalbą, publikuoti Rusijoje [91]. „Priešo“ perteikimo Rytų fronte analizei taip pat skirti keli straipsniai minètame straipsnių rinkinyje „Užmirštasis frontas“ [76]. Rytų Prūsijos atveju tas klausimas yra truputị paliestas Roberto Traba’os studijoje apie regioninę Rytų Prūsijos tapatybę tarpukariu [74]. Lietuvoje tokie klausimai kol kas neanalizuoti. Iš panašaus pobūdžio tyrimų galima ịvardyti vos vieną tekstą apie konkrečius vokiečiu ịvaizdžius, formuotus Lietuvoje per karą. Jị 2014 m. paskelbẻ Andrea Griffante [26]. Taigi su karu ir svetimos kariuomenès invazija bei okupacija susijusių ịvaizdžių kūrimasis karo metais atitinkamai Lietuvoje ir Rytų Prūsijoje, okupacijos mitologizavimas ir stereotipizavimas, diskurso apie Vokietiją ir vokiečius (Rytų Prūsijoje atitinkamai apie Rusiją ir rusus) tęstinumas tarpukariu, - visa tai daugeliu atvejų iki šiol nenagrinètos temos.

Menkai istoriografijoje tyrinètas ir karo dèmens įsikomponavimas diskurse apie ūkio ir miestų atstatymą. Vẻlgi klausimas daugiau analizuotas Rytų Prūsijos atveju: apie ji rašyta minètoje R. Traba'os studijoje [74] ir Lenkijoje 2006 m. apginto habilitacinio darbo pagrindu paskelbtoje Jano Salmo monografijoje apie Rytų Prūsijos miestų atstatymą po Pirmojo pasaulinio karo [64].

Kitas projekto tematikai svarbus klausimas - priverstinių iškeldinimų, patirtų karo metais, vėlesnis sureikšminimas ir aktualizavimas - nėra tyrinètas nei Rytų Prūsijos, nei Lietuvos atveju. Istorikų dėmesio iki šiol yra sulaukę tik priverstiniai iškeldinimai. Pirminę, „oficialią“, medžiagą apie 1914-1915 m. masinius gyventojų iškeldinimus iš Rytų Prūsijos dar tarpukariu buvo paskelbęs Karaliaučiaus istorikas Fritzas Gause [24]. Vèliau tuo klausimu doméjosi italų istorikè Serena Tiepolato [71;72]. Kelis straipsnius šia tema, naudodamas daugiausia Rusijos archyvų medžiagą, publikavo viename Maskvos archyvų dirbantis istorikas Sergejus Nelipovičius [90; 89; 88]. Dėmesio vertas ir su tema tiesiogiai susijęs Rusijos kariuomenès elgesio civilių gyventojų atžvilgiu Rytų Prūsijoje klausimas. Literatūroje šiuo klausimu esama nemažai diskusijų, ypač dèl to, kiek Rusijos kariuomenès „žvèriškumas“ buvo specialiai sureikšmintas propagandos tikslams [plg. 32, 158-159], o paskutinị straipsnị šia tema $2014 \mathrm{~m}$. paskelbė istorikas Alexanderis Watsonas [78]. Gyventojų išsikèlimą ir priverstinị iškeldinimą iš vakarinių Rusijos gubernijų savo darbuose yra palietę jau minètas S. Nelipovičius [87], Peteris Holquistas [30; 31]. Peteris Gatrellas apie tai yra parašęs visą studiją [23]. Rusijos gilumoje atsidūrusių lietuvių organizavimąsi analizavo Tomas Balkelis [6, 213-240]; apie žydų iškeldinimą iš vakarinių Rusijos gubernijų atskirai yra rašęs Anatolijus Haješas [92; kiti autoriaus tyrimai daugiausia skelbti internete]. Tačiau kaip šios iškeldinimo patirtys buvo sureikšminamos ir atmenamos vẻliau, jau po karo, iki šiol nèra analizuota.

Istoriografijoje iki šiol lieka netyrinèti ir dauguma atsiminimų apie karą, kurie gana gausiai buvo skelbiami iki 1939 m. (taip pat ir Lietuvoje), jų publikavimo dinamika ir turinys.

Nepaprastai svarbus karo sureikšminimo ir atminimo tyrimo aspektas yra vadinamųjų atsiminimų bendruomenių, kitaip tariant, karo atminimo nešèjų struktūros, poveikio ir aktyvumo viešojoje komunikacijoje atskleidimas. Daugiausia čia, suprantama, kalbama apie ịvairias karo veteranų, taip pat nukentejusiųjų kare organizacijas, kurios pokariu 
buvo masiškai steigiamos visoje Europoje. Rytų Prūsijos atveju šių organizacijų poveikị karo atminimui minètoje studijoje iš dalies paliete R. Traba [74]. Klaipèdos krašto atveju tas pats klausimas iš dalies buvo atskleistas šių eilučių autoriaus tyrimuose [61;62]. Apie karo veteranų bei karo invalidų organizacijas ir ypač jų politinị vaidmenị tarpukariu Vokietijoje pastaraisiais metais yra pasirodę nemažai naujų studijų [55; 50; 84; iš ankstesnių B. Ziemanno tyrimų ypač išskirtini 86; 85; iš ankstesnių lyginamųjų studijų žr. 12]. Lietuvoje šią temą bene pirmoji bandè plètoti Aušra Jurevičiūtė savo Vytauto Didžiojo universitete 2009 m. apgintoje disertacijoje [35]. Darbo autore pareišké, kad Pirmojo pasaulinio karo veteranai Lietuvoje integravosi ị organizacijas, kuriose būrèsi ir kitų karų, pirmiausia Nepriklausomybès karų, dalyviai, nesukurdami savo atskiros organizacijos. Pirminè medžiagos, saugomos Lietuvos archyvuose, apžvalga, atlikta pristatomo projekto dalyvių, rodo, kad ši išvada yra pernelyg skubota. A. Jurevičiūtès disertacija, deja, neatsako ị visus mums rūpimus klausimus. Svarbu, jog karo atminimo nešėjai tarpukariu galèjo vienytis nebūtinai pagal formalius kriterijus, todèl yra prasminga ieškoti ir kitų šiuo laikotarpiu egzistavusių tinklų, kurių dalyvius vienijo tam tikra karo nulemta patirtis.

Galiausiai mūšių ir karo aukų įamžinimas, karo muzealizavimas, vaidmuo edukacijoje, karo atminimo ritualizavimas ir politinis ịveiklinimas, lokalios atminimo tradicijos Lietuvoje ir Rytų Prūsijoje taip pat iki šiol analizuotos tik sporadiškai. Nors praktiniu lygmeniu karo atminimas yra nagrinètas bene išsamiausiai, ir čia susiduriame su daugybe neatsakytų klausimų. Rytų Prūsijos atveju daugiausia minètu analizès lygmeniu, suprantama, yra padirbèta tiriant Tanenbergo memorialinio komplekso kūrimą ir jo politinị eksploatavimą, taip pat Tanenbergo pergalès reikšmę Paulio von Hindenburgo kulto formavimuisi $[77 ; 82 ; 20 ; 18 ; 73 ; 65 ; 44 ; 74 ; 29]$. Šis klausimas buvo paliestas ir Lietuvos autorių [53], nors jie, tiesa, nematė būtinybès kažkaip reaguoti ì gausią ankstesnę istoriografiją apie Tanenbergo mitologizavimą po 1914-ųjų. Kitos karo atminimo praktikos Rytų Prūsijoje buvo analizuojamos minėtoje R. Traba’os studijoje [74], nors šiam autoriui karo patirtis rūpejjo tik kaip viena iš specifinio rytprūsietiško identiteto sudedamųjų. Be to, R. Traba savąją analizę apribojo 1933-iasiais, tad svarbiais pokyčiais karo patirties politiniame ịveiklinime išsiskyręs nacionalsocialistų valdymo laikotarpis jo liko neatskleistas.

Karo atminimo praktikas Lietuvoje savo straipsniuose bandè paliesti Darius Staliūnas [69; nedaug atnaujinta straipsnio versija 68] ir jau minètas V. G. Liulevičius [48]. Tiesa, abu autoriai šiuo klausimu rinkosi vienodą strategiją: konstatavę, kad Didžiojo karo atminties Lietuvoje iš esmès nebuvo, jie pereidavo prie Nepriklausomybès karų ịprasminimo praktikų ir politinio įveiklinimo Lietuvoje tarpukariu. Tai tarsi leistų daryti hipotezę, kad Lietuvoje formos ir būdai, kuriais Vakarų Europoje buvo atmenamas Didysis karas, buvo pritaikyti Nepriklausomybės karams iprasminti. A. Kasparavičius bei T. Balkelis $2014 \mathrm{~m}$. paskelbtuose straipsniuose taip pat bandè atsakyti ị klausimą, kodèl Didžiojo karo atminties Lietuvoje nebuvo [36; 5]. Anot A. Kasparavičiaus, viską paaiškina faktas, jog „Lietuva kaipo valstybė nedalyvavo Didžiajame kare su sava kariuomene, sava politika ir nacionaliniais interesais“ $[36,58]$. T. Balkelio teigimu, Didžiojo karo atmintis buvo marginalizuota „ivairių atminties transformacijų, ypač Lenkijos ir Lietuvos konflikto“ $[5,242]$. Ši tezè, taip pat ir D. Staliūno bei V. G. Liulevičiaus teiginiai vis dèlto dar turètų būti tikrinami atlikus gilesnę šaltinių analizę.

Apie lietuviškų tyrimų būklę karo atminimo praktikų klausimu iš tiesų daug ką pasako faktas, kad Lietuvoje iki šiol nèra paskelbtas ne tik karo dalyvių, bet ir jų palaidojimų registras. Rytų Prūsijoje paminklai žuvusiems Didžiajame kare yra daugiau ar mažiau 
suregistruoti $[52 ; 11]$, žinomos ir gana tikslios karių žuvimo vietos bei apytiksliai žuvusiųjų skaičiai [17]. Lietuvoje tokie duomenys buvo renkami 1919-1921 m. [36, 58], tačiau surinktos informacijos pagrindu joks registras iki šiol nebuvo parengtas ir viešai paskelbtas.

\section{VIETOJE IŠVADU}

Atminties tyrèjai žmonių atsiminimus apie praeitị kartais skirsto $\mathfrak{z}$ „karštus“ ir „šaltus“. „Karštais“ atsiminimai laikomi tuomet, kai yra gyvi praeities patirčių liudininkai arba viena, dvi kartos po jų, praeities patirtys viešojo bendravimo erdveje yra gyvai komunikuojamos, aktualizuojamos, dẻl jų laužomos ietys. „Šalti“ atsiminimai aktualizuojami retai, dèl kažkokių priežasčių to vengiama arba jie nebeaktualūs vien todèl, kad yra išmirę paskutiniai praeities ịvykių liudininkai, galintys atskleisti savąsias „autentiškas“ patirtis. Nuo Pirmojo pasaulinio karo praejus šimtui metų, apklausti gyvų liudininkų, kurių atmintis galètų tapti tyrimo apie šio karo reikšmę pagrindu, nebėra galimybès. Visgi šiuolaikiniai mokslo metodai ir tiriamosios prieigos leidžia tą reikšmę atkurti retrospektyviai. Maža to, tai, kaip visuomenè sureikšmina praeities patirtis - šiuo atveju karą, gali labai daug pasakyti ir apie pačią visuomenę, jos vertybines orientacijas ir praeities patirčių taikymą dabarčiai. Pažvelgti ị dvi skirtingas Pietryčių Baltijos regiono visuomenes tarpukariu per šią prizmę - būtent to siekiama stimuliuojant gilesnius Didžiojo karo atminimo Lietuvoje ir Rytų Prūsijoje tyrimus.

Kol kas per anksti spręsti, kiek straipsnyje pristatyta prieiga ir tiriamieji pjūviai leis verifikuoti įsigalejusią nuomonę, kad Pirmasis pasaulinis karas Lietuvos piliečiams nebuvo „savas“. Tačiau pristatytasis tyrimas turètų mažų mažiausiai sukurti sąlygas Didịji karą ”grąžinti ị atmintị", suteikdamas galimybę suvokti jo poveikį Lietuvos ir Rytų Prūsijos visuomenèms, sykiu ir nauju kampu pažvelgti ị tas visuomenes platesniame regiono kontekste.

Gauta 20150907

Priimta 20151027

\section{Šaltiniai ir literatūra}

[1] BAYLY, C. A.; BECKERT, Sven; CONNELLY, Matthew; HOFMEYR, Isabel; KOZOL, Wendy; SEED, Patricia. AHR Conversation: On Transnational History. American Historical Review, 2006, Vol. 111, No. 5, pp. 1440-1464.

[2] BALKELIS, Tomas. Demobilization and Remobilization of German and Lithuanian Paramilitaries after the First World War. Journal of Contemporary History, 2015, Vol. 50, No. 1, pp. 38-57.

[3] BALKELIS, Tomas. (De)Mobilisation of Lithuanians: From Imperial Soldiers to National Guardians. Iš: Transnational Soldiers: Foreign Military Enlistment in the Modern Era. Ed. by N. Arielli, B. Collins. London: Palgrave Macmillan, 2012, pp. 127-144.

[4] BALKELIS, Tomas. In Search of a Native Realm: The Return of World War One Refugees to Lithuania, 1918-1924. Iš: Homelands: War, Population and Statehood in Eastern Europe and Russia, 1918-1924. Ed. by N. Baron, P. Gatrell. London: Anthem Press, 2004, pp. 74-97.

[5] BALKELIS, Tomas. Memories of the Great War and the Polish-Lithuanian Conflict in Lithuania. Iš: The Empire and Nationalism at War (Russia’s Great War and Revolution, 1914-22). Ed. by E. Lohr, V. Tolz, A. Semyonov, M. von Hagen. Bloomington: Slavica Publishers, 2014, pp. 241-256.

[6] BALKELIS, Tomas. Moderniosios Lietuvos kūrimas. Vilnius: Lietuvių literatūros ir tautosakos institutas, 2012.

[7] BALKELIS, Tomas. Nation-Building and World War I Refugees in Lithuania, 1918-1924. Journal of Baltic Studies, 2003, Vol. XXXIV, No. 4, pp. 432-456. 
[8] BECKER, Annette. Les monuments aux morts: patrimoine et mémoire de la Grande Guerre. Paris: Errance, 1988.

[9] BRANDT, Susanne. Vom Kriegsschauplatz zum Gedächtnisraum: Die Westfront 1914-1940. Baden-Baden: Nomos, 2000.

[10] BROEDRICH, Immo. Die Organisation der Deutschen Hoheitsverwaltung in Kurland während des Weltkrieges und ihre Rechtsgrundlagen (Abhandlungen des Instituts für Politik, ausländisches öffentliches Recht und Völkerrecht an der Universität Leipzig). Leipzig: Universitätsverlag von Robert Noske, 1936.

[11] Cmentarze wojenne z okresu I wojny światowej w województwie olsztyńskim. Oprac. Wiktor Knercer. Warszawa: Ośrodek Ochrony Zabytkowego Krajobrazu, 1995.

[12] COHEN, Deborah. The War Come Home: Disabled Veterans in Britain and Germany, 19141939. Berkeley: University of California Press, 2001.

[13] COLLIANDER, Börje. Die Beziehungen zwischen Litauen und Deutschland während der Okkupation 1915-1918. Åbo: Tidnings Och Tryckeri Aktiebolag, 1935.

[14] CROUTHAMEL, Jason. The Great War and German Memory: Society, Politics and Psychological Trauma. Exeter: University of Exeter Press, 2009.

[15] CROUTHAMEL, Jason. An Intimate History of the Front: Masculinity, Sexuality and Ordinary German Soldiers in the First World War. New York: Palgrave Macmillan, 2014.

[16] DAVIS, Belinda. Experience, Identity, and Memory: The Legacy of World War I [review]. The Journal of Modern History, 2003, Vol. 75, No. 1, pp. 111-131.

[17] DEHNEN, Max. Die Kriegsgräber in Ostpreussen von 1914/15 (Beihefte zum Jahrbuch der Albertus-Universität Königsberg/Pr., XXVII). Würzburg: Holzner, 1966.

[18] EKDAHL, Sven. Tannenberg / Grunwald - Ein politisches Symbol in Deutschland und Polen. Journal of Baltic Studies, 1991, Vol. 22, Issue 4, pp. 271-324.

[19] FILIPPOWA, Tatjana. Von der Witzfigur zum Unmenschen. Die Deutschen in den Kriegsausgaben von „Nowyj Satirikon“ und „Krokodil“. Iš: Verführungen der Gewalt: Russen und Deutsche im Ersten und Zweiten Weltkrieg. Hrsg. von Karl Eimermacher und Astrid Volpert unter Mitarbeit von Gennadij Bordjugow. München: Wilhelm Fink, 2005, S. 267-296.

[20] FISCHER, Heike. Tannenberg-Denkmal und Hindenburgkult. Hintergründe eines Mythos. Iš: Unglücklich das Land, das Helden nötig hat. Hg. von Michael Hütt, Hans-Joachim Kunst, Ingeborg Pabst. Marburg: Jonas, 1990, S. 28-47.

[21] Frontalltag im Ersten Weltkrieg: Wahn und Wirklichkeit. Quellen und Dokumente. Hrsg. von Bernd Ulrich, Benjamin Ziemann. Frankfurt a. M.: Fischer, 1994.

[22] FUSSELL, Paul. The Great War and Modern Memory. New York and London: Oxford University Press, 1975.

[23] GATRELL, Peter. A Whole Empire Walking. Refugees in Russia during World War I. Bloomington and Indianapolis: Indiana University Press, 1999.

[24] GAUSE, Fritz. Die Russen in Ostpreußen 1914/15. Königsberg: Gräfe und Unzer, 1931.

[25] GOEBEL, Stefan. The Great War and Medieval Memory. War, Remembrance and Medievalism in Britain and Germany, 1914-1940. Cambridge: Cambridge University Press, 2006.

[26] GRIFFANTE, Andrea. La Prima guerra mondiale e l'uso pubblico della storia in Lituania: i nuovi Cavalieri teutonici. Storicamente: laboratorio di storia. Studi e Ricerche, 2014, Nr. 10, p. 1-25.

[27] GRIFFANTE, Andrea. We and Homeland: German Occupation, Lithuanian Discourse, and War Experience in Ober Ost. Iš: Other Fronts, Other Wars? First World War Studies on the Eve of the Centennial (History of Warfare, Vol. 100). Ed. by J. Bürgschwentner, M. Egger, G. Barth-Scalmani. Leiden, Boston: Brill, 2014, pp. 237-255. 
[28] [HÄPKE, Rudolf]. Die deutsche Verwaltung in Litauen 1915 bis 1918: nur zum Dienstgebrauch. Berlin: Reichsdruckerei, 1921.

[29] HOEGEN, Jesko von. Der Held von Tannenberg: Genese und Funktion des Hindenburg-Mythos. Köln, Weimar, Wien: Böhlau, 2007.

[30] HOLQUIST, Peter. To Count, to Extract, and to Exterminate. Population Statistics and Population Politics in Late Imperial and Soviet Russia. Iš: A State of Nations. Empire and NationMaking in the Age of Lenin and Stalin. Ed. by R. G. Suny, T. Martin. Oxford, New York: Oxford University Press, 2001, pp. 111-144.

[31] HOLQUIST, Peter. Les violences de l'armée russe à l'encontre des Juifs en 1915: Causes et limites. Iš: Vers la guerre totale: le tournant de 1914-1915. Ed. John Horne. Paris: Tallandier, 2010, p. 191-219.

[32] HORNE, John; KRAMER, Alan. War between Soldiers and Enemy Civilians, 1914-1915. Iš: Great War, Total War. Combat and Mobilization on the Western Front, 1914-1918. Ed. by R. Chickering, S. Förster. New York: Cambridge University Press, 2000, pp. 153-168.

[33] IRIYE, Akira. Transnational History: review article. Contemporary European History, 2004, Vol. 13, Issue 2, pp. 211-222.

[34] JAHN, Peter. „Zarendreck, Barbarendreck“ - Die russische Besetzung Ostpreußens 1914 in der deutschen Öffentlichkeit. Iš: Verführungen der Gewalt: Russen und Deutsche im Ersten und Zweiten Weltkrieg. Hrsg. von Karl Eimermacher und Astrid Volpert unter Mitarbeit von Gennadij Bordjugow. München: Wilhelm Fink, 2005, S. 223-242.

[35] JUREVIČIŪTĖ, Aušra. Buvusiu kariu organizacijos ir ju vaidmuo Lietuvos vidaus politikoje 1923-1940 m. Daktaro disertacija. Kaunas, 2009.

[36] KASPARAVIČIUS, Algimantas. La Grande Guerre dans les mémoires historiques des Lituaniens. Matériaux pour l'histoire de notre temps, 2014, No. 1-2(113-114), p. 58-65.

[37] KING, Alex. Memorials of the Great War in Britain: the Symbolism and Politics of Remembrance. Oxford \& New York: Berg, 1998.

[38] KOROWINA, Larissa. Munition ohne Patronen: Antideutsche Stimmungen und Propaganda in der russischen Armee während des Ersten Weltkriegs. Iš: Verführungen der Gewalt: Russen und Deutsche im Ersten und Zweiten Weltkrieg. Hrsg. von Karl Eimermacher und Astrid Volpert unter Mitarbeit von Gennadij Bordjugow. München: Wilhelm Fink, 2005, S. 243-266.

[39] KORTE, Barbara; SCHNEIDER, Ralf; STERNBERG, Claudia. Der Erste Weltkrieg und die Mediendiskurse der Erinnerung in Großbritannien. Autobiographie-Roman-Film (1919-1999). Würzburg: Königshausen \& Neumann, 2005.

[40] Krieg im Frieden: Die umkämpfte Erinnerung an den Ersten Weltkrieg. Hrsg. von Bernd Ulrich, Benjamin Ziemann. Frankfurt a. M.: Fischer, 1997.

[41] KOSELLECK, Reinhart. Einleitung. Iš: Politischer Totenkult: Kriegerdenkmäler in der Moderne. Hrsg. von Reinhart Koselleck, Michael Jeismann. München: Wilhelm Fink, 1994, S. 9-20.

[42] KOSELLECK, Reinhart. Kriegerdenkmale als Identitätsstiftung der Überlebenden. Iš: Identität. Hrsg. von Odo Marquard, Karlheinz Stierle. München: Wilhelm Fink, 1979, S. 255-276.

[43] KOSSERT, Andreas. Ostpreussen. Geschichte und Mythos. München: Siedler, 2005.

[44] KOSSERT, Andreas. Tannenberg 1914. Ein ostpreußischer Mythos und seine politische Dimension. Ǐs: Mare Balticum. Begegnungen zu Heimat, Geschichte, Kultur an der Ostsee (Colloquia Baltica, 1). Hrsg. von Dietmar Albrecht. München: Martin Meidenbauer Verlagsbuchhandlung, 2005, S. 87-97.

[45] Lietuvos gyventojai. Pirmojo $1923 \mathrm{~m}$. rugséjo $17 \mathrm{~d}$. visuotino gyventoju surašymo duomenys. Kaunas, [1925]. 
[46] LINDE, Gerd. Die Deutsche Politik in Litauen im Ersten Weltkrieg (Schriften der Arbeitsgemeinschaft für Osteuropaforschung der Universität Münster). Wiesbaden: Otto Harrassowitz, 1965.

[47] LIPP, Anne. Meinungslenkung im Krieg. Kriegserfahrungen deutscher Soldaten und ihre Deutung 1914-1918 (Kritische Studien zur Geschichtswissenschaft, Bd. 159). Göttingen: Vandenhoeck \& Ruprecht, 2003.

[48] LIULEVIČIUS, Vejjas Gabriel. Building Nationalism: Monuments, Museums, and the Politics of War Memory in Inter-War Lithuania. Iš: Über den Weltkrieg hinaus. Kriegserfahrungen in Ostmitteleuropa 1914-1921 (Nordost-Archiv, NF Bd. XVII/2008). Hrsg. von Joachim Tauber. Lüneburg: Nordost-Institut, 2009, S. 230-247.

[49] LIULEVIČIUS, Gabriel Vejas. War Land on the Eastern Front. Culture, National Identity, and German Occupation in World War I. Cambridge: Cambridge University Press, 2000.

[50] LÖFFELBEIN, Nils. Ehrenbürger der Nation. Die Kriegsbeschädigten des Ersten Weltkriegs in Politik und Propaganda des Nationalsozialismus. Essen: Klartext, 2013.

[51] LOPATA, Raimundas. Lietuvių Atgimimo istorijos studijos. T. 9: Lietuvos valstybingumo raida 1914-1918 metais. Vilnius: Mintis, 1996.

[52] LURZ, Meinhold. Kriegerdenkmäler in Deutschland. Bd. 3: Erster Weltkrieg; Bd. 4: Weimarer Republik. Heidelberg: Esprint, 1985.

[53] MAČIULIS, Dangiras; PETRAUSKAS, Rimvydas; STALIŪNAS, Darius. Kas laimèjo Žalgirio mūš̨į? Vilnius: Mintis, 2012.

[54] MOSSE, George L. Fallen Soldiers: Reshaping the Memory of the World Wars. Oxford: Oxford University Press, 1990.

[55] MULLIGAN, William. German Veterans' Associations and the Culture of Peace: The Case of the Reichsbanner. Iš: The Great War and Veterans' Internationalism. Ed. by J. Eichenberg, J. P. Newman. London: Palgrave Macmillan, 2013, pp. 139-161.

[56] NÜBEL, Christoph. Durchhalten und Überleben an der Westfront. Raum und Körper im Ersten Weltkrieg (Zeitalter der Weltkriege, Bd. 10). Paderborn: Ferdinand Schöningh, 2014.

[57] PETRONE, Karen. The Great War in Russian Memory. Bloomington and Indianapolis: Indiana University Press, 2011.

[58] POCIŪNAS, Arvydas. Tragiški lietuvių karių likimai Pirmajame pasauliniame kare. Karys, 2001, Nr. 3, p. 24-25; perspausdinta: Voruta, 201211 24, Nr. 24(762), p. 5.

[59] REIMANN, Aribert. Der große Krieg der Sprachen. Untersuchungen zur historischen Semantik in Deutschland und England zur Zeit des Ersten Weltkrieges. Essen: Klartext, 2000.

[60] Remembering the First World War. Ed. by B. Ziino. Abington, New York: Routledge, 2015.

[61] SAFRONOVAS, Vasilijus. Funktionale Ähnlichkeiten und Unterschiededer Erinnerungskulturen an der Wende vom 19. zum 20. Jahrhundert in Städten an der Peripherie und im Zentrum. Memel im Vergleich mit Berlin und Königsberg. Zeitschrift für Ostmitteleuropa-Forschung, 2014, 63. Jhg., Hf. 2, S. 214-248.

[62] SAFRONOVAS, Vasilijus. Kampf um Identität. Die ideologische Auseinandersetzung in Memel/Klaipéda im 20. Jahrhundert (Veröffentlichungen des Nordost-Instituts, Bd. 20). Wiesbaden: Harrassowitz, 2015.

[63] SAFRONOVAS, Vasilijus. Kultūrinè atmintis ar atminimo kultūra? Kultūrinès atminties teorijos taikymo moderniụjų laikų tyrimams problemos. Iš: Nuo Basanavičiaus, Vytauto Didžiojo iki Molotovo ir Ribbentropo: atminties ir atminimo kultūru transformacijos XX-XXI amžiuje. Sud. Alvydas Nikžentaitis. Vilnius: LII leidykla, 2011, p. 39-64.

[64] SALM, Jan. Ostpreußische Städte im Ersten Weltkrieg. Wiederaufbau und Neuerfindung 
(Schriften des Bundesinstituts für Kultur und Geschichte der Deutschen im östlichen Europa, Bd. 46). München: Oldenbourg, 2012.

[65] SCHENK, Frithjof Benjamin. Tannenberg/Grunwald. Iš: Deutsche Erinnerungsorte. Bd. I. Hrsg. von Etienne François, Hagen Schulze. München: C. H. Beck, 2001, S. 438-454.

[66] SCHNEIDER, Thomas F. Winzige schwarze Punkte. Bemerkungen zur Darstellung „des Russen“ in der deutschen Prosa zum Ersten Weltkrieg (1914-1933). Iš: Verführungen der Gewalt: Russen und Deutsche im Ersten und Zweiten Weltkrieg. Hrsg. von Karl Eimermacher und Astrid Volpert unter Mitarbeit von Gennadij Bordjugow. München: Wilhelm Fink, 2005, S. 551-572.

[67] SKIPITIS, Rapolas. Nepriklausoma Lietuva statant. Chicago: Terra, 1961.

[68] STALIŪNAS, Darius. Der Kult des Unbekannten Soldaten in Litauen. Iš: Über den Weltkrieg hinaus. Kriegserfahrungen in Ostmitteleuropa 1914-1921 (Nordost-Archiv, NF Bd. XVII/2008). Hrsg. von Joachim Tauber. Lüneburg: Nordost-Institut, 2009, S. 248-266.

[69] STALIŪNAS, Darius. Žuvusių karių kultas tarpukario Lietuvoje. Ǐs: Lietuvių Atgimimo istorijos studijos. T. 17: Nacionalizmas ir emocijos (Lietuva ir Lenkija XIX-XX a.. Sud. Vladas Sirutavičius, Darius Staliūnas. Vilnius: LII leidykla, 2001, p. 120-132.

[70] STRAZHAS, Aba. Deutsche Ostpolitik im Ersten Weltkrieg. Wiesbaden: Harrassowitz, 1993.

[71] TIEPOLATO, Serena. La deportazione di civili prussiani in Russia (1914-1920). Iš: La violenza contro la popolazione civile nella grande Guerra. Deportati, profughi, internati (Biblioteca di storia contemporanea, 19). Ed. Bruna Bianchi. Milano: Unicopli, 2006, p. 107-125.

[72] TIEPOLATO, Serena. „....und nun waren wir auch Verbannte. Warum? Weshalb?“ Deportate Prussiane in Russia 1914-1918. Deportate, Esuli, Profughe. Rivista telematica di studi sulla memoria femminile, 2004, Nr. 1, p. 59-85.

[73] TIETZ, Jürgen. Das Tannenberg-Nationaldenkmal. Architektur, Geschichte, Kontext. Berlin: Bauwesen, 1999.

[74] TRABA, Robert. Wschodniopruskość. Tożsamość regionalna i narodowa w kulturze politycznej Niemiec. Olsztyn: Borussia, 2006.

[75] Unsere Russen, unsere Deutschen: Bilder vom Anderen 1800 bis 2000 [Berlin, Schloss Charlottenburg, Neuer Flügel, 8. Dezember 2007 bis 2. März. 2008]. Hrsg. von Andrea Kamp, Peter Jahn, Philip Springer. Berlin: Christoph Links, 2007.

[76] Die vergessene Front. Der Osten 1914/15. Ereignis, Wirkung, Nachwirkung. Hrsg. von Gerhard P. Groß. Paderborn, München, Wien, Zürich: Ferdinand Schöningh, 2006.

[77] VOGELSANG, Ernst. Aus der Geschichte des Reichsehrenmals Tannenberg. Iš: Zwischen den Weltkriegen. Teil II: Kultur im Preußenlande der Jahre 1918 bis 1939. Hrsg. von Udo Arnold. Lüneburg: Nordostdeutsches Kulturwerk, 1987, S. 73-122.

[78] WATSON, Alexander. "Unheard-of Brutality": Russian Atrocities against Civilians in East Prussia, 1914-1915. The Journal of Modern History, 2014, 86(4), pp. 780-825.

[79] WATSON, Janet S. K. Fighting Different Wars: Experience, Memory, and the First World War in Britain. New York: Cambridge University Press, 2004.

[80] WESTERHOFF, Christian. Zwangsarbeit im Ersten Weltkrieg: Deutsche Arbeitskräftepolitik im besetzten Polen und Litauen 1914-1918. Paderborn, München, Wien, Zürich: Ferdinand Schöningh, 2011.

[81] WINTER, Jay. Remembering War: The Great War between Memory and History in the Twentieth Century. New Haven: Yale University Press, 2006.

[82] WINTER, Jay. Sites of Memory, Sites of Mourning: The Great War in European Cultural History. Cambridge \& New York: Cambridge University Press, 1995.

[83] WIPPERMANN, Wolfgang. Die Geschichte des „Reichsehrenmals Tannenberg“. Ein histo- 
risches Lehrstück. Niemandsland. Zeitschrift zwischen der Kulturen, 1987, 1-2, S. 58-69.

[84] ZIEMANN, Benjamin. Contested Commemorations: Republican War Veterans and Weimar Political Culture. New York: Cambridge University Press, 2013.

[85] ZIEMANN, Benjamin. Die deutsche Nation und ihr zentraler Erinnerungsort. Das „Nationaldenkmal für die Gefallenen im Weltkriege“ und die Idee des „Unbekannten Soldaten“ 19141935. Iš: Krieg und Erinnerung: Fallstudien zum 19. und 20. Jahrhundert (Formen der Erinnerung, Bd. 4). Hrsg. von Helmut Berding, Klaus Heller, Winfried Speitkamp. Göttingen: Vandenhoeck \& Ruprecht, 2000, S. 67-91.

[86] ZIEMANN, Benjamin. Republikanische Kriegserinnerung in einer polarisierten Öffentlichkeit.

Das Reichsbanner Schwarz-Rot-Gold als Veteranenverband der sozialistischen Arbeiterschaft. Historische Zeitschrift, 1998, Bd. 267, S. 358-398.

[87] НЕЛИПОВИЧ, Сергей. В поисках внутреннего врага: депортационная политика России в 1914-1918 гг. Iš: Первая мировая война и участие в ней России: материалы научной конференции, 5-6 авг. 1994 г. Москва. Т. 1. Москва: Государственная публичная историческая библиотека, 1994, с. 54-64.

[88] НЕЛИПОВИЧ, Сергей. Население оккупированных территорий рассматривалось как резерв противника. Военно-исторический журнал, 2000, № 2, с. 60-69.

[89] НЕЛИПОВИЧ, Сергей. Переселение немцев из Восточной Пруссии в Россию: „вольнопленные“, или злоключения восточнопрусских немцев в России (1914-1917). Iš: Миграционные проиессы среди российских немиев. Исторический аспект: материалы международной научной конференции. Анапа, 26-30 сентября 1997 г. Москва: Готика, 1998, с. 173-183.

[90] НЕЛИПОВИЧ, Сергей. Репрессии против подданных „центральных держав“. Военноисторический журнал, 1996, № 6, с. 32-42.

[91] Россия и Германия в ХХ веке. Т. 1: Обольщение властью. Русские и немиы в Первой и Второй мировых войнах. Ред. Карл Аймермахер, Г. Бордюгов, Астрид Фольперт. Москва: НИЦ „АИРО-ХХІ“, 2010.

[92] ХАЕШ, Анатолий. Выселение евреев из Литвы весной 1915 г. (на примере местечка Жеймели). Іš: ХАЕШ, Анатолий. Евреи Литвы: исследования и материалы (Труды по иудаике. История и этнография / Transactions on Jewish Studies. History and Ethnography, Вып. 8). Санкт-Петербург: Міръ, 2013, с. 86-108.

VASILIJUS SAFRONOVAS

\section{Remembrance of the First World War in Lithuania and East Prussia. Outline of the new research project}

Summary

The article presents a three-year research project Remembrance of the First World War: A Comparative Analysis of Lithuania and East Prussia (till 1939), funded by the Research Council of Lithuania, that was launched at the Institute of Baltic Region History and Archaeology of Klaipeda University in 2015. In the assessment of the current state of the research, the author introduces the main directions of this investigation. The research undertakings outlined in the article are expected to encourage a broader discussion on how to investigate the remembrance of war in a country that itself was not involved in that war. 
The first part of the article raises the question why it is necessary to analyze the remembrance of the Great War in Lithuania and East Prussia. To date, the experiences of that "great seminal catastrophe" (George Kennan) of the previous century have been obviously overwhelmed by the relevance of the Second World War. In addition, Lithuania belongs to those countries that already in the interwar period focused not so much on the remembrance of the Great War, but rather on the revolutionary changes caused by the war (primarily, the Wars of Independence) and the memory of their achievement. The initiation of the Great War remembrance study aims to a) encourage the relevance of the Lithuanian research in WWI, b) develop military history in Lithuania on such an interpretative level that has already been achieved in other, primarily "Western" European, countries, and c) by means of the results of the study, encourage the international community of scholars to pay attention to the little known war remembrance phenomena in the South East Baltic Region.

The second part of the article presents the novelty of the newly launched research. Here, the author argues that the remembrance of the First World War in Europe has been usually analyzed by historians focusing on one national community. In cases when the comparative research has been undertaken, it has generally handled the examples from Western and Central Europe. The article states that the presented research will differ from such comparative studies by focusing on one East European region that was the area of the same theatre of operations. The actualization of experiences related to the Eastern Front is going to be analyzed, and the Eastern Front of WW1 has been so far rarely approached by means of comparative material. Thus, the significance that was assigned to the war and its remembrance will not be compared in two countries that were active participants in the war. In fact, the novelty of the research in question comes from the comparison of two societies that had similar war experiences (although on a different scale), however, each made them significant in a different manner. In addition, the remembrance of the Great War is going to be approached here not only through the comparative but also through the transnational perspective. The research team will therefore pose the question of what configurations and transformations the same phenomenon - the significance given to, and the remembrance of, the war experiences - underwent under different social and political conditions that were characteristic of two different regions (Lithuania and East Prussia), rather than how the war was remembered individually in Lithuania and East Prussia.

The essence of such an undertaking is to analyze the remembrance of the Great War in Lithuania and East Prussia on three levels, which are conditionally called discoursive, social, and practical. On the discoursive level, the signification of particular war experiences and the means of such signification will be analyzed. On the social level, the questions will be raised what social groups were united by different war experiences and what their role was in the signification and commemoration of the war. On the practical level, the war commemoration and signification practices in Lithuania and East Prussia will be explored.

The third part of the article provides an overview of the current state of the research in the issues that are going to be analyzed during the research process.

It is expected that the implementation of the research project presented in the article should, at the very least, create the conditions for the Great War to be "returned to the memory", thus enabling one to better understand its impact on the Lithuanian and East Prussian societies and at the same time to approach those societies from a new angle in a wider regional context.

Key words: the First World War, war remembrance, remembrance history, comparative approach, transnational approach 